\title{
Is the Conduct of Serres an Anatomical Variation in Adults?
}

\author{
¿Es el Conducto de Serres una Variación Anatómica en Adultos? \\ *,**Iván Claudio Suazo Galdames; ", ** Daniela Alejandra Zavando Matamala; \& ** Ricardo Luiz Smith
}

SUAZO, G. I. C.; ZAVANDO, M. D. A. \& SMITH, R. L. Is the conduct of Serres an anatomical variation in adults? Int. J. Morphol., 27(1):43-47, 2009.

SUMMARY: In 1817, the denominated conduct of Serres was described as a formation that was highly prevalent in children's jaws, but considered as an anatomical variation in adults. In this study we analyze the presence of the denominated Serres' - conduct in 324 jaws belonging to the collection of the Universidade Federal de São Paulo (UNIFESP), with sex and age registration, 68 subadults of age between 0 and 2 years and 256 adults of age between 18 and 100 years. We found that the prevalence was in order to $100 \%$ in the subadults group and $42.6 \%$ in the adults group. In adults, the prevalence of this anatomical structure was greater in women than in men, with a difference statistically significant for the variable sex (Chi2 $=0.0148$; I.C 95\% $=0.29-0.91$; O.R. $=0.51)$. According to the age, the biggest prevalence was in the fourth decade of the life, not being of any statistical significance for this variable. Based on the opposing evidence, this article discusses the character of anatomical variation of this formation and based on the anatomical terminology, intending to denominate the paramandibular canal.

KEY WORDS: Conduct of Serres; Jaws; Anatomical variation; Anatomical terminology.

\section{INTRODUCTION}

In the jaw, besides the constant holes as the mental and the mandibular foramen, there are a great quantity of foramina and accessory foramina, which have been associated with to situations of clinical interest.

Suazo et al. (2007a) reported that the retromolar triangle region presented a great quantity of foramina connected to the mandibular canal, which would allow the diffusion of anesthetic solutions toward the inferior alveolar nerve, describing an anesthetic technique for this zone (Suazo et al., 2008; Sandoval et al., 2008). Kodera \& Hashimoto (1995) indicated that these foramina allow the anastomosis of the inferior alveolar artery with the buccal artery.

It has also been observed that lingual foramina and their canals are frequently found in adult jaws (Vasconcellos et al., 2000; Nagar et al., 2001), This should be considered in the differential diagnosis of apical lesions of the central inferior incisive and in the implant placement in that region. Narayana \& Prashanthi (2003) analyzed 335 dried mandibles and they only found a single case with an accessory mandibular foramen that originated in a canal. Das \& Suri (2004) reported another similar case whose canal was projected until the third inferior molar. In both reported cases the accessory mandibular canal was superior to the mandibular canal.

Other variants of the mandibular canal have also been described. Wadhwani et al. (2008) reported a patient who presented a mandibular canal that bifurcated in the right side and trifurcated in the left side. The literature shows that the incidence of bifurcated or trifurcated canals are low, between 0.08 and $0.95 \%$ of the analyzed cases (Nortje et al., 1977; Grover \& Lorton, 1983; Langlais et al., 1985) while Suazo et al. (2007b) did not find any variations in a sample of mature women's jaws.

From an embryological perspective variations of number in the mandibular canal can be explained because in the early development, the inferior alveolar nerve innervate the anterior teeth group, premolar and the molar region in an independent way. Later on, the rapid process of

\footnotetext{
* Departamento de Anatomía Normal, Universidad de Talca, Chile.

** Departamento de Morfología y Genética. Universidade Federal de São Paulo, Brasil.
} 
membranous ossification of the jaw determines the formation of the mandibular canal, being able to configure this division (Goret-Nicaise \& Pilet, 1983; Chavez et al., 1996).

Another probable cause that explains the foramens and accessory canal's presence is the conduct of Serres development, this formation was described by the French anatomist Antoine Étienne Reynaud Augustin Serres, in 1817. It was initially called conduct of the first teething, believed to contain a branch of the inferior alveolar artery dedicated to the irrigation of temporary teeth, but later studies determined that this formation lodges a vein, called by Figún \& Garino (2001), as vein of Serres. For Rouvière \& Delmas (1999) the conduct of Serres only contains vessels and it is obliterated soon after birth. Bergmann et al. (1984) indicated that this formation is highly prevalent in infantile jaws; in new born it reached $100 \%$. This way, the literature documents this formation in children, a situation that is contrasted with a shortage of studies in mature population, which leads us to think that the conduct of Serres in adults would not only be an anatomical variation, but also must not be well documented with the carried out anatomical observation in a habitual way. Keeping this in mind, the purpose of this study is to evaluate the presence of the denominated conduct of Serres in children's and adults jaws, to analyze its relationship with the age and sex and to discuss its nomenclature.

\section{MATERIAL AND METHOD}

For this study, 324 dried mandibles of the Universidade Federal de São Paulo's collection were used. The inclusion criterions were considered those jaws that had sex, age and death cause registered, with an appropriate conservation state that allowed its visual inspection. As exclusion criterions malformed skulls, evidence of pre and post - mortem trauma was considered. Once selected they were divided in two groups:

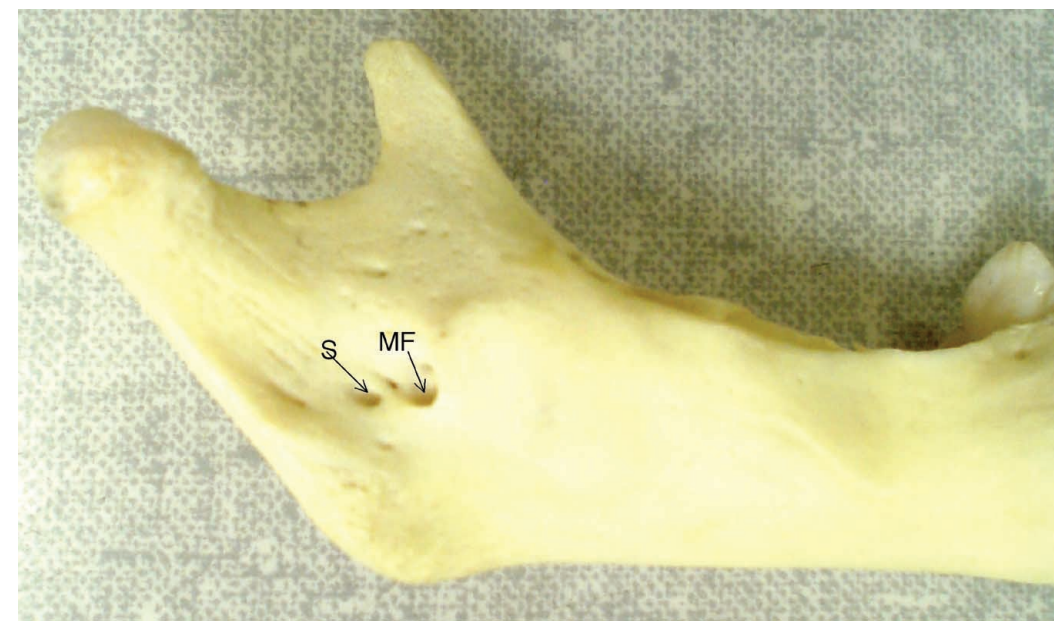

Fig. 1. Female mandible of 9 months old, medial view. $S=$ Serres's canal. FM= Mandibular foramen.

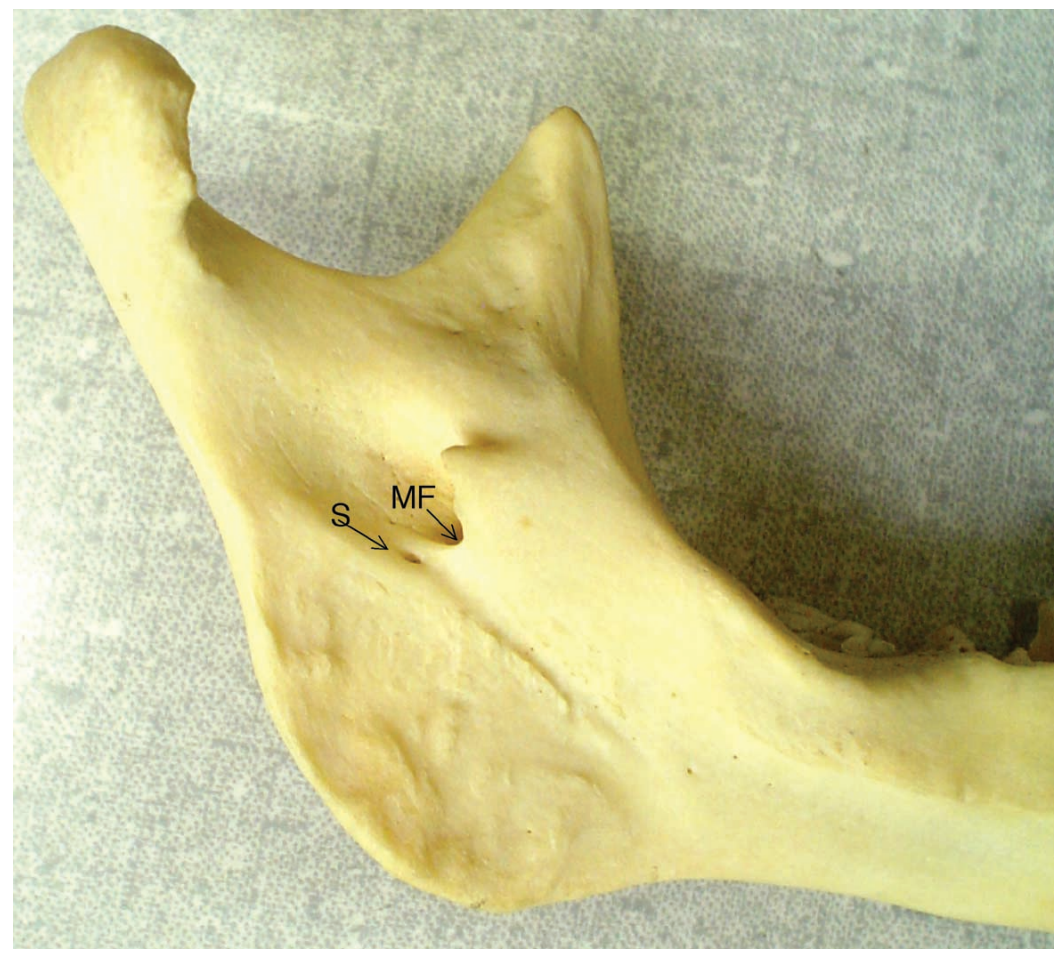

Fig. 2. Male mandible of 40 years old, medial view. $\mathrm{S}=$ Serres's canal; FM= Mandibular foramen.
Subadults jaws: constituted by 68 jaws from children's aged between 0 and 2 years of age (mean 0.50 years; SD 0.58), being 43 males and 25 females.

Adults jaws: constituted by 256 jaws from adult individuals aged between 18 and 100 years of age (mean 42.45; SD 14.932), 176 males and 80 females.

All the jaws were inspected by a single observer 
and it was considered positive for the existence of the conduct of Serres, when it was verified, by means of a simple visual observation of the medial face of the mandibular ramus, the presence of a foramen, followed by a canal oriented antero-inferiorly, of postero-inferior location with regard to the mandibular foramen and that it allowed the introduction of $2 \mathrm{~mm}$ of an semi rigid metallic instrument with $0.20 \mathrm{~mm}$ diameter (Figs. 1 and 2).

Using the statistical program SPSS 15.0, the prevalence of the denominated conduct of Serres was established in the analyzed sample and the existent relationships were studied among the sex, the individuals age, the cause of death and the presence of the conduct. The Chi squared test was used $(\mathrm{p}<0.05)$ to test statistical significance, and based on a contingency table the odds ratio value settled for the clinical significance of the presence of the conduct and the variable sex.

\section{RESULTS}

In the group of sub adult's jaws between 0 and 2 years of age, the prevalence of the denominated conduct of Serres was $100 \%$ bilateral.

In the adult's jaws, $42.6 \%$ presented Serres' conduct, being the unilateral presence of this formation in $23.4 \%$. The details of the prevalence results are shown in Table I.

Table I. Prevalence of denominated conduct of Serres in 256 adult mandibles belonging to the Universidade Federal de São Paulo's collection.

\begin{tabular}{lcc}
\hline & Frequency & Percentage \\
\hline Absent & 147 & 57.4 \\
Present right side & 29 & 11.3 \\
Present left side & 31 & 12.1 \\
Bilateral & 49 & 19.1 \\
Total & 256 & 100.0
\end{tabular}

To analyze the gender-based differences in the prevalence of the denominated conduct of Serres, we found that out of the analyzed adults jaws, 66 males and 43 females presented the formation; nevertheless, due to the difference in the distribution of males and females in the sample, the prevalence was greater in the women's group, with $57.35 \%$, while in men it was of $37.5 \%$. These differences were significant with a value chi $2=0.0148$ and an Odds Ratio 0.51 . The chart of contingency of the prevalence of the conduct of Serres in adult's individual's jaws by sex, is shown in the Table II.
Table II. Contingency table of the conduct of Serres prevalence in adults' mandibles by sex.

\begin{tabular}{lrcc}
\hline Conduct of Serres & Male & Female & Total \\
Present & 66 & 43 & 109 \\
Absent & 110 & 37 & 147 \\
Total & 176 & 80 & 256 \\
Odds ratio & & 0.51 & \\
\hline Chi $^{2}$ & & $0.0148^{*}$ & \\
\hline Confidence intervale 95\% & & $0.29-0.91$ & \\
* Statistic Significance $\mathrm{p}<0.05$ & &
\end{tabular}

When the presence of the formation is studied in relation with the age in the adult jaws collection, we do not find any positive or negative correlation. The mean age in the group that presented the denominated conduct of Serres was 42.18 years (SD 15.612), while the mean age in the jaws without conduct of Serres was 42.65 years (SD 14.548). The biggest prevalence was in individuals' jaws of the fourth decade (30-39 years) with $24.44 \%$.

The distribution according to age of the denominated conduct of Serres in the group that presented the formation is shown in Table III.

Table III. Frequency of distribution of the conduct of Serres in 109 adults mandibles, belonging to the Universidade Federal de São Paulo’s collection.

\begin{tabular}{lccc}
\hline Decade & Age range & Frequency $\mathrm{F}=\mathrm{S} / \mathrm{T} .{ }^{*}$ & Percentage** $^{* *}$ \\
\hline $2^{\circ}$ & $10-19$ & $1 / 3$ & 0.91 \\
$3^{\circ}$ & $20-29$ & $19 / 43$ & 17.40 \\
$4^{\circ}$ & $30-39$ & $31 / 73$ & 28.44 \\
$5^{\circ}$ & $40-49$ & $24 / 58$ & 22.01 \\
$6^{\circ}$ & $50-59$ & $18 / 34$ & 16.51 \\
$7^{\circ}$ & $60-69$ & $10 / 32$ & 9.17 \\
$8^{\circ}$ & $70-79$ & $3 / 9$ & 2.75 \\
$9^{\circ}$ & $80-89$ & $2 / 3$ & 1.83 \\
$10^{\circ}$ & $90-99$ & $0 / 0$ & 0.00 \\
$11^{\circ}$ & $100-109$ & $1 / 1$ & 0.91 \\
\hline
\end{tabular}

* The frequency $(\mathrm{F})$ is expressed in numbers of cases which presented conduct of Serres (S), relationship with numbers of cases of the total sample, groups by each age range $(\mathrm{T})$.

** The percentage was calculated on the basise of 109 cases with conduct of Serres presence.

\section{DISCUSSION}

Starting from the research of Serres, various authors have reported the presence of a foramen that originates in a 
canal, which continues parallel to the later segment of the mandibular canal. This formation was related from its first description with the irrigation and the veined drainage of the temporary teeth's system and of the alveolar processes in formation. From birth, this canal suffers a gradual obliteration during the first year of life (Figún \& Garino). It has been observed that the denominated conduct of Serres is highly prevalent in children's jaws in the first years of life (Bergmann et al.), and this coincides with the observations in this study, where the entirety of the analyzed jaws presented visible and permeable bilateral foramens and canals. Our sample only analyzed jaws between 0 and 2 years, nevertheless, not reported observations suggest that the prevalence is also high in other subadults groups. Further investigations need to be carried out in more jaws of children.

The prevalence of the denominated conduct of Serres in the individuals adults jaws was significantly greater in woman than in men. These indications are based on the analyzed sample where for each one adult's masculine jaw that presents the formation, we found two feminine jaws with the same formation (Table II. O.R. Value).

When we analyze the data of adult's jaws, the results were interesting. We found that in $42.6 \%$ the foramen and the studied canal was present and permeable and this differs considerably to that found in the literature, most of which considers the denominated conduct of Serres as a variation in adult's jaws. The gradual obliteration with the age is also debatable. The present study observes the formation in almost all the ages, the biggest concentration in the fourth and fifth decades of life and its decrease in older subjects were findings related to the distribution of the sample ages.

With these data, the character of anatomical variation of the formation analyzed in this study is questionable. According to Alves \& Candido (2007), an anatomical variation is a fickle formation, of low prevalence that does not imply pathology; these authors also define the normality in statistical terms, as that is a more frequent way without developing into pathology.

Finally, the denomination conduct of Serres should be revised, beginning from the general concepts of anatomical terminology. The names of the structures should be indicative of morphological traits that guide the reader about a location, its forms or function and the eponyms should be suppressed (International Anatomical Nomenclature Committee, 1989; Federative Committee Anatomical Terminology, 2000)

For instance, the term "conduct" refers to a structure of soft walls, but with the analyzed formation being a structure of hard walls, this then should be called "canal". With these considerations, besides the parallel orientation to the mandibular canal, we intend to replace the name of the foramen and conduct of Serres with paramandibular foramen and canal.

SUAZO, G. I. C.; ZAVANDO, M. D. A. \& SMITH, R. L. ¿Es el conducto de Serres una variación anatómica en adultos? Int. J. Morphol., 27(1):43-48, 2008.

RESUMEN: El denominado conducto de Serres es una formación descrita en 1817, como altamente prevalente en mandíbulas de niños, pero considerado una variación anatómica en adultos. En este estudio analizamos la presencia del denominado conducto de Serres en 324 mandíbulas pertenecientes a la colección de la Universidade Federal de São Paulo, con registro de sexo y edad, 68 de subadultos de entre 0 y 2 años y 256 de adultos de entre 18 y 100 años. Nosotros encontramos un 100\% de prevalencia en el grupo de subadultos y un $42.6 \%$ en el grupo de adultos. En adultos, la prevalencia de esta estructura anatómica fue mayor en mujeres que en hombres, con una diferencia estadísticamente significativa para la variable sexo $\left(\mathrm{Chi}^{2}=0.0148 ; \mathrm{I} . \mathrm{C}\right.$ 95\%=0.29-0.91; O.R.=0.51). De acuerdo a la edad, la mayor prevalencia se encontró en la $4^{\mathrm{a}}$ década de la vida, no encontrándose significancia estadística para esta variable. En base a la evidencia encontrada, en este artículo se discute el carácter de variación anatómica de esta formación y basado en la terminología anatómica se propone denominarla canal paramandibular.

PALABRAS CLAVE: Conducto de Serres; Mandíbulas; Variación anatómica; Terminología Anatómica.

\section{REFERENCES}

Alves, N. \& Candido, P. Anatomía para o Curso de Odontología Geral e Específica. $1^{\mathrm{a}}$ ed. São Paulo, Editora Santos, 2007.

Bergmann, M.; Wendler, D.; Bertolini, R. Accessory mandibular canals in the human. Anat Anz., 156(4):293302. 1984.

Chavez-Lomeli, M. E.; Mansilla Lory, J.; Pompa, J. A.; Kjaer, I. The human mandibular canal arises from three 
separate canals innervating different tooth groups. $J$. Dent. Res., 75:1540-4. 1996.

Das, S. \& Suri, R. An anatomico-radiological study of an accessory mandibular foramen on the medial mandibular surface. Folia Morphol., 63 (4):511-3, 2004.

Federative Committee Anatomical Terminology (FCAT). Terminologia Anatomica. International Anatomical Terminology. Thieme, New York, 2000.

Figún, M. \& Garino, R. Anatomía Odontológica Funcional y Aplicada. $2^{\mathrm{a}}$ ed. Buenos Aires, El Ateneo, 2001.

Goret-Nicaise M. \& Pilet, D. A Few Observations About Meekel's Cartilage in the Human. Anat Embryol., 167:365 370.1983.

Grover, P. S. \& Lorton, L. Bifid mandibular nerve as a possible cause of inadequate anaesthesia in the mandible. J. Oral Maxillofac. Surg., 41:177-9, 1983.

International Anatomical Nomenclature Committee. Nomina Anatomica. $6^{\text {th }}$. ed. Edinburgh, Churchill Livingstone, 1989.

Kodera, H. \& Hashimoto, I. A case of mandibular retromolar canal: elements of nerves and arteries in this canal. Kaibogaku Zasshi, 70(1):23-30, 1995.

Langlais, R. P.; Broadus, R. \& Glass, B. J. Bifid mandibular canals in radiographs. J. Am. Dent. Assoc., 110:923-6. 1985

Nagar, M.; Bhardwaj, R. \& Prakash, R. Accessory Lingual Foramen in Adult Indian Mandibles. J. Anat. Soc. India. 50(1):13-14, 2001.

Narayana, K. \& Prashanthi, N. Incidence of large accessory mandibular foramen in human mandibles. Eur. J. Anat., 7 (3):139-41, 2003.

Nortje, C. J.; Farman, A. G. \& Grotepass, F. W. Variations in the normal anatomy of the inferior dental (mandibular) canal: a retrospective study of panoramic radiographs from 3612 routine dental patients. Br. J. Oral Surg., 15:55-63. 1977.

Rouvière, H. \& Delmas, A. Anatomía Humana Descriptiva, Topográfica y Funcional. 10ª . ed. Barcelona, Editorial Masson, 1999. V. 3.
Sandoval, M. C. ; Suazo, G. I. C. ; Cantin, L. M. G. \& López, F. B. Pilot Study of the inferior alveolar nerve block anesthesia via the retromolar triangle in patients of 40 to 60 Years. Int. J. Odontostomatol., 2(1):1720,2008 .

Serres, A. E. R. A. Essai sur l'anatomie et la physiologie des dents, ou novelle théorie de la dentition. $1^{\text {st }}$ edition, Paris, Ed. Chez Mequignon-Marvis, 1817.

Suazo, G. I.; Cantín, L. M.; López, F. B.; Valenzuela, U. V. \& Valenzuela, R. R. Morphometric Study of the Retromolar Triangle. Int. J. Odontostomatol., 1(2):129:32, 2007a.

Suazo, I.; Cantín, M. \& Zavando, D. Inferior alveolar nerve block anesthesia via retromolar triangle, an alternative for patients with blood discrasias. Med. Oral Patol. Oral Cir. Bucal, 13(1):E43-7, 2008.

Suazo, G. I. C. ; Morales, H. C. A ; Cantin, L. M. G. \& Zavando, M. D. A. . Aspectos biométricos del canal mandibular. Int. J. Morphol., 25:805-10, 2007 b.

Vasconcellos, H. A.; Siqueira C. A. E.; Almeida, G. H.; Maia, M. L. T. \& Barros, de V. P. H. Anatomía del canal y foramen lingual y sus relaciones con la sínfisis mandibular. Rev. Chil. Anat., 18(1):47-51, 2000.

Wadhwani, P.; Mathur, R.; Kohli, M \& Sahu, R. Mandibular canal variant: a case report. J. Oral Pathol Med., 37:122-4, 2008.

Correspondence to:

Prof. Dr. Iván Suazo Galdames

Departamento de Anatomia Normal

Universidad de Talca

Avenida Lircay s/n Oficina $N^{\circ} 104$

Talca - CHILE

Email: isuazo@utalca.cl

Received: 25-10-2008

Accepted: 28-11-2008 
